\title{
PENERAPAN DIVERSI PADA ANAK BERHADAPAN HUKUM DITINJAU DARI PERSPEKTIF MASLAHAH MURSALAH
}

\author{
1Sheila Kusuma Wardani Amnesti dan ${ }^{2}$ M. Aunul Hakim \\ 1,2Fakultas Syariah, UIN Maulana Malik Ibrahim Malang \\ ${ }^{1}$ sheilakusuma@uin-malang.ac.id dan 2aunulhakim@gmail.com
}

\begin{abstract}
Diversion is an effort to resolve child criminal cases that are carried out outside the court and become the main principle adopted by the Juvenile Criminal Justice System in Indonesia. This study uses a normative juridical method with a case approach approach. This study was conducted in order to determine the effectiveness of the implementation of diversion in terms of fiqh Maslahah Mursalah. So far, the implementation of diversion has been quite successful, in which cases that reached the prosecutor's office within a period of 2 years were completed at the diversion stage and did not continue in the judicial process. Where diversion is a form of embodiment of restorative justice in Indonesia. This is in accordance with how the Maslahah Mursalah principle applies which takes more benefits than harm in determining a law
\end{abstract}

Keyword: Diversion, Restorative Justice, Maslahah Mursalah

\section{Abstrak}

Diversi merupakan upaya penyelesaian perkara pidana anak yang dilakukan di luar pengadilan dan menjadi prinsip utama yang dianut oleh Sistem Peradilan Pidana Anak di Indonesia. Penelitian ini menggunakan metode yuridis normative dengan pendekatan case approach. Penelitian ini dilakukan dalam rangka mengetahui efektivitas pelaksaan diversi dengan ditinjau dari fiqh Maslahah Mursalah. Dalam pelaksanaan diversi sejauh ini cukup berhasil dimana dari kasus yang sampai pada tingkatan kejaksaan pada kurun waktu 2 tahun selesai pada tahap diversi dan tidak berlanjut pada proses peradilan. Dimana diversi sebagai bentuk perwujudan keadilan restorative di Indonesia. Hal tersebut sesuai dengan bagaimana prinsip Maslahah Mursalah berlaku dimana mengambil lebih banyak manfaat daripada mudharat dalam penentuan sebuah hukum.

Kata Kunci: Diversi, Keadilan Restoratif, Maslahah Mursalah 


\section{PENDAHULUAN}

Anak merupakan generasi penerus sekaligus aset suatu bangsa. Keberhasilan suatu Negara dalam menanamkan adab dan ilmu pengetahuan secara seimbang dapat menjadi bekal anak-anak sebagai calon penerus estafet kepemimpinan suatu bangsa nantinya. Memasuki era society 5.0 dimana ilmu pengetahuan berkembang secara cepat dan teknologi dipergunakan di semua bidang, diperlukan bekal yang cukup bagi generasi anak dalam menghadapi segala tantangan pada masa Disruption Era ini.

Dengan perubahan dan dinamika masyarakat yang terjadi pada Disruption Era ini perlu ada filter terhadap pola pikir masyarakat khususnya anak-anak. Dengan kecepatan akses teknologi atau media daring dapat mengakibatkan banyaknya informasi yang dapat diakses dengan mudah. Dimana informasi yang didapat tersebut dapat bersifat baik maupun tidak baik. Pada situasi kondisi tertentu hal tersebut mengakibatkan anak terpengaruh untuk melakukan perbuatan karena dinamika perubahan yang terjadi secara cepat di masyarakat. Dengan pengaruh informasi tersebut mengakibatkan pergeseran terhadap adab dan tata karma yang semakin menurun. Sebagaimana pendapat dari Sumiati, bahwa kenakalan remaja merupakan suatu perilaku yang dilakukan oleh remaja dengan mengabaikan nilai-nilai sosial yang berlaku di dalam masyarakat. Dimana kenakalan remaja tersebut meliputi semua perilaku yang menyimpang atas suatu norma dan hukum yang dilakukan oleh remaja. Akhirnya perilaku tersebut dapat menimbulkan kerugian diri anak sendiri maupun orang lain (Sumiati, 2009). Dapat diartikan lebih lanjut bahwa kenakalan remaja merupakan kecenderungan remaja dalam berbuat atau bertindak melanggar aturan yang mengakibatkan kerugian pada dirinya sendiri maupun pada orang lain.

Dalam perspektif islam perilaku seorang remaja atau anak dipengaruhi oleh pola pendidikan dari keluarga terutama orang tua. Sebagaimana orangtua menjadi tempat pendidikan pertama anak, khususnya seorang ibu yang menjadi sosok madrosatul ula dimana ibulah yang berperan sebagai madrasah (sekolah) pertama anaknya. Hal tersebut secara langsung menempatkan posisi orang tua sebagai pondasi anak dalam membentengi sekaligus menyaring dari arus negatif yang begitu cepat berkembang dewasa ini. Dikutip dari hadist yang diriwayatkan oleh Al Baihaqi dari kakek Ayub Bin Musa Al Quraisy dari Nabi shalallaahu 'alaihi wa sallam bersabda,"Tiada satu pemberian yang lebih utama yang diberikan ayah kepada anaknya selain pengajaran yang baik" (Fiona, 2021). Dapat diartikan bahwa merupakan suatu kewajiban dari orangtua untuk senantiasa mengajarkan kebaikan dan memfasilitasi pendidikan yang baik untuk anaknya. 
Pola parenting dan komunikasi antara anak dengan orang tua yang kurang efektif dapat memicu terjadinya potensi perilaku menyimpang dari aturan oleh seorang remaja. Pada akhirnya apabila anak ataupun remaja tersebut bertindak melanggar aturan memiliki konsekuensi sebagaimana sanksi dari norma/kaidah yang telah dilanggar. Ketika anak atau remaja melangar hukum akibat tindakan melanggar hukum maka peraturan yang dirujuk yakni Undang-Undang Nomor 11 Tahun 2012 tentang Sistem Peradilan Pidana Anak. Sebelum UU tersebut diciptakan telah didahului oleh UU Nomor 3 Tahun 1997 tentang Pengadilan Anak. Perbedaan mendasar antara pola pembinaan Anak dengan orang Dewasa yang melanggar hukum yakni pada proses persidangan serta penempatannya. Dimana anak yang berhadapan dengan hukum yang telah menjalani proses peradilan dapat ditempatkan pada Lembaga Pembinaan Khusus Anak/LPKA (Pasal 81 UU No. 12/2011). Sebelum sampai pada tahapan pembinaan di LPKA, dalam UU No.12/2011 secara substantive memuat alternative penyelesaian perkara di luar peradilan sebagai bentuk restorative justice. Upaya penyelesaian perkara pidana anak di luar proses peradilan anak salah satunya diversi. Diversi sebagaimana dimuat dalam Pasal 1 angka7 UU No. 12/2011 diartikan sebagai pengalihan penyelesaian perkara anak dari proses peradilan pidana ke proses di luar peradilan pidana.

Prinsip diversi memberi keleluasaan penerapan beberapa azas dalam sistem peradilan anak diantaranya Azas kepentingan terbaik bagi anak dan azas kelangsungan hidup dan tumbuh kembang anak sebagaimana termuat pada Pasal 2 UU No. 12/2011. Bahwa anak yang berhadapan dengan hukum tetap memiliki hak untuk bertumbuh kembang dan menjadi pribadi yang lebih baik kedepan. Dari pandangan konsep Maslahah Mursalah dimana menetapkan hukum baru dengan mengambil mana yang lebih mewujudkan banyak manfaat, menolak kemudharatan dan menghilangkan kesusahan manusia (Aris, 2013), tentu diversi merupakan kaidah baru dalam alternative penyelesaian perkara pidana anak. Meski status anak merupakan anak yang berhadapan dengan hukum tentu harus tetap mendapat perlakuan yang baik selama proses Peradilan Pidana Anak. Penelitian mengenai Diversi telah dilakukan sebelumnya oleh Azwad Rachmat Hambali dengan judul Penerapan Diversi terhadap Anak yang Berhadapan Dengan Hukum dalam Sistem Peradilan Pidana. Hasil penelitian tersebut menunjukkan aparat penegak hukum dalam melaksanakan tugas baik penyidikan, penuntutan, pemeriksaan dan penentuan putusan perkara pada sidang pengadilan hendaknya mengutamakan penerapan diversi sebagai salah satu alternatif dari penerapan pidana penjara. Akan tetapi belum terlihat adanya perspektif lain khususnya pandangan dari Maslahah Mursalah pada kajian penelitian tersebut. Oleh sebab itu penelitian kali ini akan 
mengankat perspektif Masalahah Mursalah pada penerapan Diversi. Sehingga perlakuan terhadap anak berhadapan dengan hukum harus senantiasa memperhatikan proses-proses perlindungan anak dan tetap menjunjung tinggi harkat dan martabat anak tanpa mengabaikan prinsip keadilan dan bukan membuat nilai kemanusiaan anak menjadi lebih rendah sebagaimana prinsip Masalahah Mursalah.

\section{KAJIAN PUSTAKA \\ Diversi}

Salah satu wujud perlindungan kepada anak yang berhadapan dengan hukum yakni diversi. Dalam UU SPPA definisi Diversi merupakan pengalihan penyelesaian perkara Anak dari proses peradilan pidana ke proses di luar peradilan pidana. Model diversi bertujuan untuk menghindari serta menjauhkan anak dari proses peradilan secara formal sehingga dapat menghindari stigmatisasi terhadap anak yang berhadapan dengan hukum dan diharapkan anak dapat kembali ke dalam lingkungan sosial secara wajar. Menurut Nasir Djamil pengertian Diversi dalam bukunya Anak Bukan Untuk Dihukum ialah suatu pengalihan penyelesaian kasus-kasus anak yang diduga melakukan tindak pidana tertentu dari proses pidana formal ke penyelesaian damai antara tersangka/terdakwa/pelaku tindak pidana dengan korban yang difasilitasi oleh keluarga dan/atau masyarakat, Pembimbing Kemasyarakatan Anak, Polisi, Jaksa atau Hakim (Djamil, 2013). Oleh sebab itu, sangat diperlukan peran serta semua pihak dalam rangka mewujudkan upaya tersebut. Proses diversi harus memiliki tujuan pada terciptanya keadilan restoratif, baik bagi anak maupun bagi korban. Upaya Diversi dalam keadilan restorative merupakan suatu proses bahwa semua pihak yang terlibat dalam suatu tindak pidana tertentu bersama-sama mengatasi masalah serta menciptakan suatu kewajiban untuk membuat segala sesuatunya menjadi lebih baik dengan melibatkan korban, anak, dan masyarakat dalam mencari solusi untuk memperbaiki, rekonsiliasi, dan menentramkan hati yang tidak semata-mata berdasarkan prinsip pembalasan.

Penerapan diversi dilatarbelakangi keingininan untuk menghindari dampak negatif, khususnya terhadap jiwa dan perkembangan anak yang berpotensi terjadi apabila penyelesaian proses pidana nya dilakukan melalui sistem peradilan pidana (Priamsari, 2018). Implementasi diversi dalam sistem peradilan pidana anak menjadi penting karena dengan penerapan diversi, hakhak asasi anak dapat lebih terjamin dan menghindarkan anak yang berhadapan dengan hukum dari stigma anak nakal karena tindak pidana yang diduga melibatkan seorang anak sebagai pelaku dapat ditangani tanpa melalui proses litigasi (Hambali, 2019). 


\section{Anak Berhadapan Hukum}

Berdasarkan UU Sistem Peradilan pidana Anak yang dimaksud anak berhadapan dengan hukum adalah anak yang berkonflik dengan hukum, anak yang menjadi korban tindak pidana, dan anak yang menjadi saksi tindak pidana.(Pasal 1 Angka 2 UU No. 11/2012). Lebih lanjut penjelasan mengenai anak berhadapan dengan hukum diantaranya mencakup Anak berkonflik dengan huum yang selanjutnya disebut anak adalah anak yang telah berumur 12 (dua belas) tahun, tetapi belum berumur 18 (delapan belas) tahun yang diduga melakukan tindak pidana. Selain itu, Anak yang menjadi korban tindak pidana yang selanjutnya disebut sebagai anak korban adalah anak yang belum berumur 18 (delapan belas) tahun yang mengalami penderitaan fisik, mental, dan/atau kerugian ekonomi yang disebabkan oleh tindak pidana. Cakupan anak berhadapan dengan hukum selanjutnya yakni Anak yang menjadi saksi tindak pidana yang selanjutnya disebut anak saksi adalah anak yang belum berumur 18 (delapan belas) tahun yang dapat memberikan keterangan guna kepentingan penyidikan, penuntutan, dan pemeriksaan di sidang pengadilan tentang suatu perkara pidana yang didengar, dilihat, dan/atau dialaimnya sendiri.

Harry E. Allen and Clifford E. Simmonsen mendefinisikan bahwa ada 2 (dua) klasifikasi perbuatan anak yang membuat anak harus berhadapan dengan hukum (Purniati, dkk, 2003), yaitu: 1. Status Offence yang merupakan perilaku kenakalan anak dimana apabila dilakukan oleh orang dewasa tidak dianggap sebagai kejahatan, seperti tidak menurut, membolos sekolah, atau kabur dari rumah; 2. Juvenile Deliquence adalah perilaku kenakalan anak yang apabila dilakukan oleh orang dewasa dianggap kejahatan atau pelanggaran hukum. Dari penjelasan tersebut bahwa anak yang berhadapan dengan hukum atau anak yang bermasalah dengan hukum yakni mereka yang berkaitan langsung dengan tindak pidana, baik itu anak sebagai korban maupun saksi dalam suatu tindak pidana. Di sisi lain terdapat perbedaan dari perilaku atau perbuatan melawan hukum anak dan orang dewasa yang tidak bisa di samakan, dimana sebuah perbuatan yang dilakukan anak bisa saja menjadi suatu perbuatan melawan hukum, namun untuk orang dewasa itu tidak termasuk dalam perbuatan melawan hukum, maupun sebaliknya.

Mengenai proses peradilan anak setiap anak yang berhadapan dengan hukum tetap memiliki hak untuk diperlakukan secara manusiawi dengan memperhatikan kebutuhan sesuai dengan umurnya. Disamping hak tersebut, anak berhadapan dengan hukum berhak memperoleh bantuan hukum dan bantuan lain secara efektif. Serta adanya hak lain seperti tidak ditangkap, ditahan, atau dipenjara, kecuali sebagai upaya terakhir dan dalam waktu yang paling singkat (Pasal 3 UU No.11/2012). 
Terdapat beberapa perbedaan dari anak yang berhadapan dengan hukum dan orang dewasa yang melakukan tindak pidana dimana perbedaan tersebut adalah dari segi pemidanaannya, berdasarkan Undang-Undang Sistem Peradilan Pidana Anak Pasal 71 ayat (1) pidana pokok untuk anak yang berhadapan dengan hukum yaitu: a. pidana peringatan; b. pidana dengan syarat: 1) pembinaan di luar lembaga; 2) pelayanan masyarakat; atau 3) pengawasan. c. pelatihan kerja; d. pembinaan dalam lembaga; dan e. penjara. Lain halnya dengan KUHP, diaman pidana pokok telah disebutkan pada KUHP Pasal 10, meliputi: a. pidana mati, b. pidana penjara, c. kurungan, dan d. denda. Perbedaan Anak Berhadapan dengan Hukum dan pelaku dewasa ini terlihat dalam pemidanaannya, pelaku dewasa hukuman mati merupakan pidana terakhir untuk pelaku dewasa, sedangkan anak adalah penjara itupun untuk sebagai alternatif terakhir dan tidak diperbolehkan adanya hukuman mati atau penjara seumur hidup.

\section{Masalahah Mursalah}

Berdasarkan pendapat ulama Al-Syatibi, sebagai pemuka madzhab Maliki, menjelaskan bahwa al-maslahah al-mursalah adalah tiap-tiap prinsip syara' yang tidak disertai bukti nash khusus, namun sesuai dengan tindakan syara' serta maknanya diambil dari dalil-dalil syara'. Dengan demikian prinsip tersebut sah sebagai dasar hukum sepanjang telah menjadi prinsip dan digunakan syara' yang qath'I (Aini, 2017). Prinsip al-mashlahah al-mursalah dapat dijadikan sebagai dalil hukum secara mandiri. Bagi kalangan Malikiyah, al-mashlahah al-mursalah bukan berarti tidak memiliki legitimasi syara' sama sekali, namun secara tidak langsung meskipun jauh tetap memiliki legitimasi syara' karena tidak ada legitimasi secara jelas tentang diterima maupun ditolaknya (Syafe'i, 2007). Pendapat Imam Malik, berdasarkan kajian dari alSyatibi, mendefinisikan al-maslahah al-mursalah sebagai sebuah maslahah yang sesuai dengan tujuan, prinsip serta dalil-dalil syara' dengan fungsi untuk menghilangkan kesempitan, baik yang bersifat dharuriyah maupun hajiyah (Syafe'i, 2007).

Untuk bisa menjadikan mashlahah mursalah sebagai dalil dalam menetapkan hukum, ulama Malikiyyah dan Hanabilah mensyaratkan tiga syarat, yaitu; (1) Kemashlahatan itu sejalan dengan kehendak syara' dan termasuk dalam jenis kemaashlahatan yang didukung nash secara umum, (2) Kemashlahatan itu bersifat rasional dan pasti, bukan sekedar perkiraan sehingga hukum yang ditetapkan melalui mashlahah al-mursalah itu benarbenar menghasilkan manfaat dan menghindari atau menolak kemudaratan, (3) Kemashlahatan itu menyangkut kepentingan orang banyak, bukan kepentingan pribadi atau kelompok kecil tertentu (Haroen, 1997). 


\section{METODE}

Artikel ini menggunakan metode penelitian merupakan penelitian yuridis normatif, dengan mengkaji peraturan perundang-undangan serta teori yang berkaitan dengan maslahah mursalah. Selanjutnya data yang diperoleh dianalisis secara deskriptif kualitatif dengan pendekatan kasus (Ishaq, 2017).

\section{HASIL PENELITIAN DAN PEMBAHASAN}

\section{Efektivitas Penerapan Diversi Pada Tingkatan Pemeriksaan di Kejaksaan}

Sejak diberlakukannya Undang-Undang Nomor 11 Tahun 2012 tentang Sistem Peradilan Pidana Anak upaya Diversi menjadi sorotan bagi para penegak hukum termasuk pemerhati hukum terhadap terelenggaranya perlindungan atas anak yang berhadapan dengan hukum. Upaya diversi sebagai penyelesaian kasus pidana anak di luar pengadilan merupakan suatu bentuk keadilan restorative yang ingin diupayakan di Indonesia. Berdasarkan pandangan Zulva (2009) restorative justice sendiri merupakan konsep pemikiran yang merespon pengembangan sistem peradilan pidana dengan menitikberatkan pada kebutuhan pelibatan masyarakat dan korban yang dirasa tersisihkan dengan mekanisme yang bekerja pada sistem peradilan pidana yang ada pada saat ini. Prinsip utama dalam sistem peradilan pidana anak bahwa penerapan hukum pidana terhadap anak semata-mata bukan sebuah upaya pembalasan, melainkan dimasukkannya unsur-unsur pembinaan dalam penyelesaian kasus anak yang berhadapan hukum.

Upaya diversi dilakukan pada setiap tahapan proses pemeriksaan anak berhadapan dengan hukum dimulai dari diversi pada tingkat kepolisian, kejaksaan hingga pengadilan. Berdasarkan data yang penulis himpun sepanjang 2 tahun terakhir yakni pada tahun 2020 dan 2021, khususnya di Kejaksaan Negeri Salatiga mengenai penyelesaian kasus secara diversi yakni sebagai berikut:

Tabel 1. Penyelesaian Kasus secara Diversi

\begin{tabular}{|c|c|c|c|c|}
\hline Tahun & \multicolumn{2}{|c|}{ Kasus Posisi } & Pasal & Penyelesaian \\
\hline 2020 & \multicolumn{2}{|c|}{ Penggelapan dan Penipuan } & 372 KUHP & Diversi \\
\hline 2020 & \multicolumn{2}{|c|}{ Pencurian } & 363 KUHP & Diversi \\
\hline 2020 & \multicolumn{2}{|l|}{ Pencurian } & 363 KUHP & Diversi \\
\hline 2020 & \multicolumn{2}{|l|}{ Pengeroyokan } & 170 KUHP & Diversi \\
\hline 2020 & \multicolumn{2}{|l|}{ Pencurian } & 363 KUHP & Diversi \\
\hline 2020 & \multicolumn{2}{|c|}{ Kekerasan Terhadap Anak } & UU No.35/2014 & Diversi \\
\hline 2021 & \multicolumn{2}{|l|}{ Anak } & $\begin{array}{l}\text { Pasal } 81 \text { ayat (2) } \\
\text { Jo Pasal } 76 \text { D UU } \\
\text { No } 17 \text { Tahun } 2016\end{array}$ & Diversi \\
\hline 2021 & $\begin{array}{l}\text { Persetubuhan } \\
\text { Anak }\end{array}$ & Terhadap & $\begin{array}{l}\text { Pasal } 81 \text { ayat (2) } \\
\text { Jo Pasal } 76 \text { D UU } \\
\text { No } 17 \text { Tahun } 2016\end{array}$ & Diversi \\
\hline
\end{tabular}


Berdasarkan data wawancara dengan Kasi Tindak Pidana Umum Kejari Salatiga Nopember 2021, pada table 1 diatas dalam rentang 2 tahun terakhir yakni antara tahun 2020-2021 menunjukkan bahwa penerapan diversi dalam penyelesaian tindak pidana yang dilakukan oleh anak di bawah umur cukup efektif. Dimana dari 9 data perkara anak yang berhadapan hukum semua selesai pada tahapan diversi khususnya pada tahapan pemeriksaan di tingkat kejaksaan. Dapat disimpulkan bahwa implementasi diversi menghadirkan alternative penyelesaian perkara kasus anak berhadapan dengan hukum selain dengan proses melalui jalur litigasi atau peradilan. Secara keseluruhan atau $100 \%$ dari kasus/perkara anak yang berhadapan dengan hukum dimana ditangani kejaksaan negeri Salatiga sukses dan selesai dalam tahapan diversi.

\section{Penerapan Diversi pada Anak yang Berhadapan dengan Hukum dalam Perspektif Maslahah Mursalah}

Dengan keberhasilan implementasi diversi sebagai perwujudan keadilan restorative merupakan langkah yang inovatif dan berkemajuan pada proses peradilan pidana anak. Dimana penyelesaian terhadap kasus pidana anak bukan menekankan pada pembalasan melainkan senantiasa memperhatikan unsur pembinaan dan pembimbingan anak, mempertimbangkan kelangsungan hidup dan tumbuh kembang anak serta faktor kepentingan terbaik bagi anak.

Dalam pandangan Maslahah Mursalah dimana menitikberatkan pada konsep pelaksanaan sebuah norma/hukum yang benar-benar menghasilkan manfaat dan menghindari atau menolak kemudaratan diversi merupakan konsep ideal dalam penyelesaian perkara pidana anak. Anak pelaku dan korban dalam hal ini masih memiliki masa depan yang panjang sehingga perlu banyak pertimbangan pada penyelesaian perkara anak yang mengutamakan lebih banyak manfaat kepada anak yang berhadapan hukum tersebut. Beberapa fenomena yang terjadi dalam proses diversi yakni anak korban dan pelaku yang mencari keadilan dapat dihadirkan pada satu majelis/forum dengan difasilitasi para penegak hukum baik dari kepolosian, kejaksaan. Dari forum diversi masing-masing pihak baik anak pelaku dengan korban/ keluarga/kuasa hukumnya menyampaikan pandangannya kembali terkait perkara yang dihadapi dengan ditengahi para penegak hukum. Hal tersebut merupakan salah satu jenis bentuk syuro' dimana sebuah upaya mencari pendapat dari orang yang diajak bermusyawarah (Al-Jawi, 2010). Sebagaimana Proses syuro' yang dilakukan pada masa sahabat Rasulullah dalam menjalankan roda pemerintahan didasarkan atas ajaran AlQur'an yakni didasarkan pada firman Allah SWT: "dan bermusyawarahlah dengan mereka dalam urusan itu. Kemudian apabila kamu telah membulatkan tekad, maka bertawakallah kepada 
Allah. Sesungguhnya Allah menyukai orangorang yang bertawakal kepada-Nya" (QS Ali Imran: 159)

Penyampaian pandangan dari masing-masing pihak dalam perkara anak berhadapan dengan hukum sebagai langkah-langkah pross diversi menghasilkan kesimpulan yang cukup memuaskan para pihak. Dimana pada akhirnya dari konsepsi syura yang diterapkan dalam penyelesaian kasus anak berhadapan hukum tersebut masing-masing pihak sepakat untuk tidak melanjutkan proses perkara di tingkat peradilan/litigasi. Hal tersebut selaras dengan perspektif Maslahah Mursalah yang mengakomodir manfaat lebih banyak daripada mudharat. Dengan terselesaikannya perkara anak yang berhadapan dengan hukum pada tingkatan diversi manfaat yang diperoleh diantaranya:

1. Terlaksananya perlindungan terhadap hak-hak anak yang berhadapan dengan hukum

2. Terpenuhinya pembinaan dan pembimbingan anak di luar pengadilan

3. Penghindaraan atas upaya pembalasan

4. Penghargaan terhadap pendapat anak

5. Memperhatikan kepentingan yang terbaik bagi masa depan anak

6. Terciptanya keadilan atas masing-masing pihak

Beberapa manfaat yang didapat dengan implementasi diversi tersebut tentunya lebih diutamakan dari sekedar memberi hukuman sebagai efek jera dan pembalasan atas tindak/perilaku anak yang berhadapan dengan hukum. Dimana penekanannya atas manfaat yang lebih banyak didapat daripada mudharat. Meskipun selesai pada proses diversi anak berhadapan hukum tetap mendapat pelajaran dan pembinaan terkait perkara yang dihadapi.

\section{KESIMPULAN}

Bahwa pelaksanaan diversi merupakan upaya perwujudan menuju keadilan restorative. Dimana menitikberatkan tidak hanya pada upaya pembalasan terhadap pelaku kejahatan. Diversi pada tingkat kejaksaan dikatakan efektif dan berhasil sesuai dengan data yang telah dipaparkan. Bahwa anak yang berhadapan dengan hukum mempunyai hak untuk tetap memiliki masa depan dan tumbuh kembangnya. Dengan pertimbangan dari perspektif Maslahah Mursalah dimana mengambil dari kebanyakan manfaat daripada mudharat bahwa diversi sebagai konsep yang sesuai dengan pertimbangan dari banyak manfaat yang didapat dengan diterapkannya diversi. Dimana masing-masing pihak merelakan terwujudnya keadilan restorative selain dari upaya semata-mata untuk pembalasan perbuatan pidana. 


\section{DAFTAR PUSTAKA}

Aris. (2013). Pemikiran Imam Syafi'i Tentang Kedudukan Maslahah Mursalah Sebagai Sumber Hukum, Jurnal Hukum Diktum, 11(1), 93-99 https://media.neliti.com/media/publications/285420-pemikiran-imamsyafii-tentang-kedudukan-e1a8e46f.pdf.

Fiona, Dresyamaya. (2021). 7 Kewajiban Orang Tua Terhadap Anak Dalam Islam, Apa Saja?, Orami Parenting, https://www.orami.co.id/magazine/kewajiban-orang-tua-pada-anakdalam-islam/.

Hambali, Azwad Rachmat. (2019). Penerapan Diversi Terhadap Anak Yang Berhadapan Dengan Hukum Dalam Sistem Peradilan Pidana, Jurnal Ilmiah Kebijakan Hukum, 13(1), 15 https://doi.org/10.30641/kebijakan.2019.V13.15-30.

Purniati, Mamik, Sri Supatmi, Ni, and Made Martini Tinduk. (2003). Correction in America An Introduction, Analisa Situasi Sistem Peradilan Pidana Anak (Juvenile Justice System) Di Indonesia. Jakarta: UNICEF.

Ishaq. (2017). Metode Penelitian Hukum Dan Penulisan Skripsi, Tesis, Serta Disertasi. Bandung: ALFABETA.

http://repository.uinjambi.ac.id/73/1/Book-Metode Penelitian Hukum dan Penulisan Skripsi Tesis serta Disertasi_Ishaq.pdf.

Djamil, M. Nasir. (2013). Anak Bukan Untuk Dihukum: Catatan Pembahasan UU Sistem Peradilan Pidana Anak (UU-SPPA). Jakarta: Sinar Grafika.

Haroen, Nasrun. (1997). Ushul Fiqh I. Cet 2. Jakarta: PT Logos Wacana Ilmu.

Priamsari, Rr Putri A. (2018). 'Mencari Hukum Yang Berkeadilan Bagi Anak Melalui Diversi', Law Reform, 14(2), pp.220. https://doi.org/10.14710/lr.v14i2.20869.

Syafe'i, Rachmat. (2007). Ilmu Ushul Fiqih. Bandung: Pustaka Setia.

Al-Jawi, Shiddiq. (2010). Syura Bukan Demokrasi', p. 89.

Aini, Siti Maryam Qurotul. (2017), 'Al-Mashlahah Al-Mursalah Dan Permasalahannya', Portal Jurnal Online Kopertais Wilayah IV, 72 https://core.ac.uk/download/pdf/231313971.pdf.

Sumiati. (2009). Kesehatan Jiwa Remaja Dan Konseling. Jakarta: Trans Info Media. 
Undang-Undang Nomor 11 Tahun 2012 tentang Sistem Peradilan Pidana Anak.

Zulfa, Eva Achjani. (2009). Keadilan Restoratif. Jakarta: Fakultas Hukum Universitas Indonesia. 